\title{
Effect of Different Physiological Parameters on the Growth of Alternaria cucumerina var. cyamopsidis (Rang. and Rao)
}

\author{
Suresh Kumar ${ }^{1}$, Ashok Kumar Meena ${ }^{1}$ and Prabhu Narayan Meena ${ }^{1,2 *}$ \\ ${ }^{1}$ College of Agriculture, Department of Plant Pathology, Swami Keshwanand Rajasthan \\ Agricultural University, Bikaner- 334 006, Rajasthan, India \\ ${ }^{2}$ ICAR-Central Research Institute for Jute and Allied Fibres, Barrackpore, \\ Kolkata, 700 120, India \\ *Corresponding author
}

\section{A B S T R A C T}

\begin{tabular}{|c|}
\hline Keywords \\
\hline $\begin{array}{l}\text { Alternaria cucumerina } \\
\text { var. cyamopsidis (Rang. } \\
\text { and Rao), Carbon } \\
\text { sources, Nitrogen } \\
\text { sources, Temperatures } \\
\text { and pH and Czapex'sdox } \\
\text { agar }\end{array}$ \\
\hline Article Info \\
\hline $\begin{array}{l}\text { Accepted: } \\
20 \text { August } 2018 \\
\text { Available Online: } \\
\text { 10 September } 2018\end{array}$ \\
\hline
\end{tabular}

Clusterbean [Cyamopsis tetragonoloba (L.) Taub], is a drought resilient leguminous crop grown on sandy soils of arid and semi-arid regions. Clusterbean is infected by several fungal, bacterial and viral diseases but Alternaria blight disease caused by Alternaria cucumerina var. cyamopsidis (Rang. and Rao) considered as one of the most devastating diseases in the guar growing areas of Rajasthan. The main aim of this study was to know the effect of different carbon sources, various nitrogen sources, different range of temperatures and $\mathrm{pH}$ on the biochemical and physical dynamics with Czapex'sdox agar basal medium under in vitro conditions against Alternaria cucumerina var. cyamopsidis. Maximum mycelial growth was observed on glucose $(85.00 \mathrm{~mm})$ followed by maltose $(61.66 \mathrm{~mm})$, dextrose $(59.66)$ as compared to sucrose used as control $(89.66 \mathrm{~mm})$. Similarly, maximum mycelial growth was observed by applying potassium nitrate (78.00 $\mathrm{mm})$ as nitrogen source. In case of temperature, maximum mycelial growth $(88.66 \mathrm{~mm})$ was observed at $30^{\circ} \mathrm{C}$ followed by $(34.00 \mathrm{~mm})$ minimum mycelial growth at $20^{\circ} \mathrm{C}$. Among all the tested over a wide range of $\mathrm{pH} 5.0$ to 9.0, maximum mycelial growth $(89.33 \mathrm{~mm})$ was observed at $\mathrm{pH} 6.0$ and minimum mycelial growth $(37.33 \mathrm{~mm})$ at $\mathrm{pH} 9.0$ respectively.

\section{Introduction}

The clusterbean [Cyamopsis tetragonoloba (L.) Taub], bushy annual herb have a deep rooted system, is a resilient and drought resilient leguminous crop grown on sandy soils of arid and semi-arid regions. Clusterbean is also popularly known as Guar. It is a very hardy and drought tolerant crop. Its deep penetrating root enables plant to utilize available moisture more efficiently and thus find better scope for rainfed cropping. The crop survives best even at moderate salinity and alkalinity. There is no other legume crop so hardy and drought tolerant as clusterbean and hence suitable for cultivation in arid and semi-arid tracts of Rajasthan. Clusterbean is being grown in India since ancient time. Although believed to be of African origin (Vavilov, 1951), it was domesticated centuries ago in the NorthWestern region of the Indo Pakistan sub- 
continent (Hymowitz, 1972). Tender green guar pods are important source of nutrition to human being and animals. It is grown for different purposes viz., vegetable, green fodder, green manure and production of seeds and used as a concentrate for animals and for extraction of gum, mainly present in the seed endosperm, provides a useful raw material for a wide range of industrial products (Joshi and Arora, 1993). Seeds of clusterbean contain 28 to 33 per cent gum and it is used in almost all types of industries viz., textile, paper, petroleum, pharmaceuticals, food processing, cosmetics, mining, explosives and oil drilling etc. Besides these, it increases fertility of soil by fixing considerable amount of atmospheric nitrogen. Guar gum and its derivatives are in great demand all over the world. Clusterbean is grown in India, Pakistan, Indonesia, America, Italy, Mexico, Brazil and South Africa. India is the leading country in the world concerning area and production of guar, where it occupies 55.8 lakh hectares with annual production of 27.51 million tonnes of seed (Anonymous, 2015-16). India produced 82 per cent of total guar production in the world followed by Pakistan 15.6 per cent and 2.4 per cent USA, Brazil and others. In India, this crop is mostly grown in the state of Rajasthan, Haryana, Punjab, Uttar Pradesh and Madhya Pradesh. Rajasthan occupies 47.8 lakh hectares area with production of 22.23 million tonnes with productivity of $465 \mathrm{~kg} \mathrm{ha}$ 1 (Anonymous 2015-16). It has potential productivity of about $1500 \mathrm{~kg} \mathrm{ha}{ }^{-1}$. In Rajasthan, it is mainly grown in Barmer, Churu, Sriganganagar, Nagaur, Jalore, Sikar, Jaisalmer, Bikaner, Jaipur, Jhunjhunu, Hanumangarh and Alwar districts. The production of guar has been low and static mainly because of its cultivation under rainfed areas, marginal and sub-marginal lands, mixed cropping, low fertility status of soil and inadequate adoption of plant protection measures. Although numbers of varieties with stable yield have been released which can be grown well under rainfed conditions but these varieties are susceptible to an array of phytopathogenic fungal, viral and bacterial diseases (Anonymous, 1999).

The production and productivity of clusterbean in terms of grain and fodder is highly affected by a number of phytopathogenic fungal and bacterial diseases viz., Bacterial blight (Xanthomonas axonopodis pv. cyamopsidis), Alternaria blight (Alternaria cucumerina var. cyamopsidis), Anthracnose (Colletotrichum capsici f. sp. cyamopsicola), Curvularia leaf spot (Curvularialunata), Charcoal rot/Damping off (Macrophomina phaseolina), Dry root rot/Leaf blight (Fusarium solani and Rhizoctonia solani), Myrothecium leaf spot (Myrothecium roridum), Powdery mildew (Oidiopsis taurica) and Wilt (Fusarium caeruleum). Among the diseases, Alternariablight is a destructive fungal disease caused by Alternaria cucumerina var. cyamopsidis, which is a major foliar disease of clusterbean in Northern India (Rangaswami and Rao, 1957). This disease alone has been reported to be responsible for reduction in yield by 55.76-58.70 per cent under artificial epiphytotic conditions (Gupta, 1994). The disease appears year after year in mild to severe form, since the pathogen is seed borne in nature (Sowell, 1965). Alternaria blight is a major disease in North India. In early stages of infection, the water soaked spots appear on leaf blade which later turn greyish to dark brown with concentric zonation, demarcated with light brown lines inside the spot on the under surface. The lesions are light to greyish brown. In severe infection several spots coalesce together involving a major portion of the leaf blade. In such cases, the leaflet becomes chlorotic and usually drops off. If the plants are infected in the early stages of the growth then there may not be any flowering and pod formation. The maximum severity of the blight takes place between 
bloom and pod setting. Higher yield losses (43-78 \%) were recorded when leaves were infected at seedling stage than at old stage (Sharma, 1983).The time of appearance as well as intensity of Alternaria blight varies from variety to variety, area to area, one crop season to other and climatic conditions. In changing climatic conditions the pathogen grow very fast and appear early during cropping season. These environmental factors directly and indirectly favour the sporulation and perpetuation of diseases and hampering the production in all the clusterbean growing areas especially in rainfed condition. Keeping in view the importance of alternaria blight disease of clusterbean causing by pathogen Alternaria cucumerina var. cyamopsidis, the present investigations were carried out to unravel the effect of carbon sources, various nitrogen sources, different range of temperatures and $\mathrm{pH}$ dynamics on mycelial growth of Alternaria cucumerina var. cyamopsidis.

\section{Materials and Methods}

Alternaria blight affected leaves of clusterbean were collected from Research Farm, College of Agriculture, SKARU, Bikaner. The pathogen was isolated from diseased leaves on Potato Dextrose Agar (PDA) and purified by using single spore isolation technique (Riker and Riker, 1936). Pure culture was maintained and stored in refrigerator at $5^{\circ} \mathrm{C}$ for further studies. The different physiological studies were evaluated in vitro against Alternaria cucumerina var. cyamopsidis by following Poisoned Food Technique (Schmitz, 1930).

\section{Biochemical dynamics}

\section{Effect of carbon sources}

To find out the effect of various carbon sources on mycelial growth of Alternaria cucumerina var. cyamopsidis, the sucrose content of basal medium, Czapek'sdox agar was substituted by adding different sources of carbon on equivalent basis (12.63 $\mathrm{g}$ in $30 \mathrm{~g}$ of sucrose). Inoculated Petri dishes containing basal medium supplemented with different carbon sources were incubated at $28 \pm 2^{\circ} \mathrm{C}$ for 7 days and the mycelial growth was recorded. Carbon sources used were: glucose $\left(\mathrm{C}_{6} \mathrm{H}_{12} \mathrm{O}_{6}\right)$, dextrose $\left(\mathrm{C}_{6} \mathrm{H}_{12} \mathrm{O}_{6}\right)$, fructose $\left(\mathrm{C}_{5} \mathrm{H}_{12} \mathrm{O}_{6}\right)$, maltose $\left(\mathrm{C}_{12} \mathrm{H}_{22} \mathrm{O}_{11}\right)$ and sucrose $\left(\mathrm{C}_{12} \mathrm{H}_{22} \mathrm{O}_{11}\right)$ as control. Three replications were maintained for each treatment. The average colony diameter of $A$. cucumerina was observed after 7 days.

\section{Effect of nitrogen sources}

Effect of different nitrogen sources were studied on the growth of Alternaria cucumerina var. cyamopsidis, sodium nitrate of basal medium, Czapek'sdox agar medium was substituted by adding different sources of nitrogen on equivalent basis (329 $\mathrm{mg}$ in $2 \mathrm{~g}$ of sodium nitrate). The inoculated Petri dishes containing basal medium supplemented with different nitrogen sources were viz; urea, ammonium chloride, potassium nitrate, ammonium nitrate and sodium nitrate as control, incubated at $28 \pm 2{ }^{\circ} \mathrm{C}$ for 7 days and observation for mycelial growth of fungi was recorded. Three replications were maintained for each treatment. The average colony diameter of $A$. cucumerina was observed after 7 days.

\section{Physiological dynamics}

\section{Effect of temperature}

It is a well-known phenomenon that the different range of temperature considerably influences the biochemical activity of pathogens. The influence of temperature on mycelial growth of A. cucumerina of clusterbean isolate was determined on PDA at 
$20{ }^{0} \mathrm{C}, 25{ }^{0} \mathrm{C}, 30{ }^{\circ} \mathrm{C}$, and $35{ }^{0} \mathrm{C}$. Mycelial bit from the actively growing three days-old cultures were placed in the centre of Petri dishes and three replications were incubated in incubator maintaining five different temperature levels. Three replications were maintained for each treatment. The average colony diameter of $A$. cucumerina was observed after 7 days.

\section{Effect of hydrogen ion concentration $(\mathrm{pH})$}

Effect of different hydrogen ion concentration on the growth of fungus was studied on growth medium at different $\mathrm{pH}$ levels i.e. 5.0, 6.0, 7.0, 8.0 and 9.0. The initial $\mathrm{pH}$ of the basal medium before autoclaved was adjusted with a difference of 0.5 using $\mathrm{N} / 10 \mathrm{NaOH}$ or $\mathrm{N} / 10 \mathrm{HCl}$. After autoclaving, the $\mathrm{pH}$ was again tested. The inoculated Petri plates were incubated at $28 \pm 2^{\circ} \mathrm{C}$ for 7 days. Three replications were maintained for each treatment. The average colony diameter of A.cucumerina was observed after 7 days.

\section{Results and Discussion}

Effects of different physiological and biochemical dynamics were evaluated on the mycelial growth of $A$. cucumerina. The results reveal that mycelial growth of $A$. cucumerina was different on Czapek's Dox Agar basal medium with different carbon sources.Maximum mycelial growth was observed on glucose $(85.00 \mathrm{~mm})$ followed by maltose $(61.66 \mathrm{~mm})$, dextrose (59.66) compared to sucrose used as a control (89.66 $\mathrm{mm}$ ) and the minimum mycelial growth $(58.33 \mathrm{~mm})$ was observed on fructose after 7 days inoculation. The growth was gradually increased after inoculation of active fungus culture with all the carbon sources. The fructose containing medium supported less growth of mycelium in same conditions (Table 1). Ramjegathesh and Ebenezar (2012), reported that maximum mycelial growth were recorded with maltose $(8.82 \mathrm{~cm})$ followed by glucose $(8.67 \mathrm{~cm})$, sucrose $(8.29$ $\mathrm{cm}$ ) and fructose $(7.83 \mathrm{~cm})$, while the carboxy methyl cellulose had the minimum mycelial growth $(7.39 \mathrm{~cm})$ compared to control which are very similar and conformity with the our results on different carbon sources. Similarly, Nallathambi and Thakore (2004) reported that when maltose was used as a carbon source in the basal medium, it favored significantly highest mycelial growth of A. alternata followed by sucrose that was also harmony to our studies. Pallavi and Gupta (2013) showed the phosphate solubilisation activity of Pseudomonas lurida at different carbon sources and revealed that glucose activated the maximum phosphate solubilisation activity $10^{\text {th }}$ day at $10^{\circ} \mathrm{C}$ followed by maltose at $7^{\text {th }}$ day at $10^{0} \mathrm{C}$. A. cucumerina was grown on different nitrogen sources containing Czapek's dox agar basal medium.

The results depicted from table 1 revealed that maximum mycelial growth was observed by applying potassium nitrate $(78.00 \mathrm{~mm})$ as nitrogen source followed by ammonium nitrate $(32.33 \mathrm{~mm})$, ammonium chloride $(26.00 \mathrm{~mm})$ and urea $(24.00 \mathrm{~mm}$ minimum $)$ as compared to sodium nitrate used as a control (88.66).Among all the tested nitrogen sources, urea was found as least supportive to the mycelial growth of Alternaria cucumerina var. cyamopsidis. The present findings are in accordance with the studies of Ramjegathesh and Ebenezar (2012), they concluded that potassium nitrate produced the maximum mean mycelial growth $(9.00 \mathrm{~cm})$ followed by sodium nitrate $(7.32 \mathrm{~cm})$ and ammonium molybdate $(6.18 \mathrm{~cm})$, while thiourea had minimum mean mycelial growth $(2.63 \mathrm{~cm})$ in A. alternata. Similarly, Rajmane and Korekar (2012) reported that sodium nitrate was the best nitrogen source followed by calcium nitrate for A. alternata causing post-harvest disease of mango fruits that also corroborated to our findings. 
The mycelial growth of Alternaria cucumerina var. cyamopsidis was studied by incubating Petri dishes at different temperature levels ranging from $20^{\circ} \mathrm{C}$ to $35^{\circ} \mathrm{C}$. Maximum mycelial growth $(88.66 \mathrm{~mm})$ was observed at $30^{\circ} \mathrm{C}$. Minimum mycelial growth $(34.00 \mathrm{~mm})$ was observed at $20^{\circ} \mathrm{C}$. There was a significant difference among the different temperature levels e.i. $25^{\circ} \mathrm{C}(68.66$ $\mathrm{mm})$ followed by $35^{\circ} \mathrm{C}(50.66 \mathrm{~mm})$. Decreasing trend of mycelial growth of test fungus was observed at $35^{\circ} \mathrm{C}$ temperature (Table 2). These results show the maximum growth at $30^{\circ} \mathrm{C}$, which are very much similar and conformity with the results concluded by Singh and Prasada (1973), they reported that $30^{\circ} \mathrm{C}$ as the optimum temperature for mycelial growth of Alternaria cucumerina var. cyamopsidis followed by 20,25 and $35^{\circ} \mathrm{C}$. Khare et al., (2012) observed that the best growth and maximum sporulation of the pathogen occurred at $25^{\circ} \mathrm{C}$. Lowest growth without any sporulation was observed at $15^{\circ} \mathrm{C}$, and the growth was completely inhibited at $30^{\circ} \mathrm{C}$. Similarly, Chohan et al., (2015) observed maximum growth of $A$. solaniat $25^{\circ} \mathrm{C}(7.50 \mathrm{~cm})$ on PDA medium at $6.5 \mathrm{pH}(8.34 \mathrm{~cm})$ under continuous light condition $(9.00 \mathrm{~cm})$ that studies also supported to our findings.

The mycelial growth rate of Alternaria cucumerina var. cyamopsidis of clusterbean isolate was measured at $\mathrm{pH}$ levels ranging from 5.0 to 9.0. The findings results revealed that hydrogen ion concentration also affected the growth of Alternaria cucumerina var. cyamopsidis. Maximum mycelial growth $(89.33 \mathrm{~mm})$ was observed at $\mathrm{pH} 6.0$ and minimum mycelial growth $(37.33 \mathrm{~mm})$ at $\mathrm{pH}$ 9.0. Decreasing trend of mycelial growth of test fungus was started from $\mathrm{pH} 7.0$ to 9.0 (Table 2). The results are very much similar and conformity with the results concluded by Hubbali (2010) that the growth of A. alternata was maximum in $\mathrm{pH}$ range of 6.0- 6.5 and temperature range of $25-30^{\circ} \mathrm{C}$. Khare et al., (2012) concluded that the best growth and good sporulation occurred at $\mathrm{pH} 6.0$ and $\mathrm{pH}$ 7.0. Poor growth with fewer spores was observed at $\mathrm{pH} 5.0$ and very little growth with no sporulation at $\mathrm{pH} 8.0$ and $\mathrm{pH} 9.0$, that also harmony to our studies. Gupta et al., (2013) also found that the $\mathrm{pH} 6.5$ was the best, followed by 7.5 and good at 5.5, and 8.5. It was also observed that $\mathrm{pH} 4.5$ was poor, followed by 3.5 and 9.0 for mycelial growth of Alternarialini. In changing climatic conditions there is lots of genetic variability exist in the pathogens. So, it is important to understand the morphological, physical and biochemical dynamics that helpful in management of several devastating diseases. Hence, it can be concluded from the results of the present investigation that Alternaria cucumerina var. cyamopsidis grown best on glucose (carbon source), Potassium nitrate (nitrogen source), $30^{\circ} \mathrm{C}$ temperature and $\mathrm{pH}$ 6.0 .

\section{Acknowledgement}

The authors are grateful to the Head of the Department, Plant Pathology, College of Agriculture, SKARU, Bikaner for providing the support to undertake the investigation.

\section{References}

Anonymous, 1999, Annual Report of All India Co-ordinated Research Project on Arid-Legumes. RAU, Bikaner, pp.140.

Anonymous, 2015-16, Directorate of Agriculture. Agriculture Statistics. Government of Rajasthan, Jaipur.

Chohan, S., Perveen, R., Mehmood, M. A., Naz, S. and Akram, N., 2015, Studies on morpho-physiological, management and screening of tomato germplasm against Alternaria solani, the causal agent of tomato early blight. Dep.Patho.Pak. 17(1): 111-118. 
Gupta, P. P., 1994, Assessment of yield losses in different genotypes of clusterbean against important diseases. Annual Report of All India Coordinated Research Project of Arid Legumes. pp. $1-14$.

Gupta, S. L., Rizvi, G. and Paijwar, M. S., 2013, Alternarialini causes blight disease on linseed: Its growth response on different parameters. Adv. Life Sci. 2(2): 64-66.

Hubbali, M., Nakkeeran, S., Raguchander, T., Anand, T. and Samiyappan, R., 2010. Effect of environmental conditions on growth of Alternaria alternata causing leaf blight of noni. World J. Agri. Sci. 6(2): 171-177.

Hymowitz, T., 1972. The trans-demostication concept as applied to guar. Econ. Bot. 26: 49-60.

Joshi, U. N. and Arora, S. K., 1993, Recent advances in guar gum chemistry and utilization -A Review. Forage Res. 19: 31-328.

Khare, K. B., Otanga, R. R. N., Achwanya, O.S. and Otaye, D. O., 2012, Effect of media, $\mathrm{pH}$ and temperature on growth and sporulation of Cercosporazeaemaydis, the causal agent of grey leaf spot of maize. Inter. J. Food, Agri. Veterinary. 2(2): 87-90.

Nallathambi P. and Thakore, B. L., 2004, Effect of nutrients and $\mathrm{pH}$ on the growth and toxin production by Alternaria alternata causing fruit rot in ber. Indian J. Mycol. Pl. Pathol.34: 683-686.

Pallavi K. P. and Gupta P. C., 2013, Effect of different carbon and nitrogen sources on solubilization of insoluble inorganic phosphate by psychrotolerant bacterial strains. The Bioscan. 8(4): 1299-1302.

Rajmane, S. D. and Korekar, S. L., 2012, Impact of carbon and nitrogen sources on pectinase production of post-harvest fungi. Curr. Botany. 3(3): 01-03.

Ramjegathesh, R. and Ebenezar, E. G., 2012, Morphological and physiological characters of Alternaria alternata causing leaf blight disease of onion. Int. J. Pl. Pathol. 10(7): 01-11.

Rangaswami, G. and Rao, A.V., 1957, Alternaria blight of clusterbean [Cyamopsis tetragonoloba (L.) Taub]. Indian Phytopathol. 10: 13-18.

Riker, A.J. and Riker, R. S., 1936, Introduction to research on plant diseases. Jhon and Swift Co., Inc., New York.

Schmitz, H., 1930, Poisoned Food Technique. 2nd Edn., Industry of Engineering Chemical, London, USA. pp. 333-361.

Sharma, S. R., 1983, Effect of fungicides on the development of Alternaria blight and yield of clusterbean. Indian $J$. Agric. Sci. 53 (11): 932-935.

Singh, S. and Prasada, R., 1973, Physiology and control of Alternaria cyamopsidis, the incitant of blight disease of guar. Indian J. Mycol. Pl. Pathol.3 (1): 33-39.

Sowell, P.G., 1965, The effect of seed treatment on seed borne pathogens of guar. Pl. Dis. Reptr. 49: 895-897.

Vavilo, N. I., 1951, The origin, variation, immunity and breeding of cultivated plants. Chron. Bot. 13: 364.

\section{How to cite this article:}

Suresh Kumar, Ashok Kumar Meena and Prabhu Narayan Meena. 2018. Effect of Different Physiological Parameters on the Growth of Alternaria cucumerina var. cyamopsidis (Rang. and Rao). Int.J.Curr.Microbiol.App.Sci. 7(09): 2993-2998.

doi: https://doi.org/10.20546/ijcmas.2018.709.372 